\title{
Review: A Sikhim Road-Book
}

Source: The Geographical Journal, Vol. 18, No. 2 (Aug., 1901), pp. 161-162

Published by: geographicalj

Stable URL: http://www.jstor.org/stable/1775337

Accessed: 26-06-2016 13:45 UTC

Your use of the JSTOR archive indicates your acceptance of the Terms \& Conditions of Use, available at

http://about.jstor.org/terms

JSTOR is a not-for-profit service that helps scholars, researchers, and students discover, use, and build upon a wide range of content in a trusted digital archive. We use information technology and tools to increase productivity and facilitate new forms of scholarship. For more information about JSTOR, please contact support@jstor.org.

The Royal Geographical Society (with the Institute of British Geographers), Wiley are collaborating with JSTOR to digitize, preserve and extend access to The Geographical Journal 


\section{REVIEWS.}

\section{ASIA. \\ A SikHIm RoAD-Book.*}

We note that the forms Sikkim and Kangchinjunga are here preferred to those used in the more recent surveys, Sikhim and Kanchinjinga. It seems desirable that the Government of India should adopt finally a single form of local names. Another detail which calls for remark is the discrepancy between many of the heights given on the sketchmap attached to this volume and those in the large-scale (2 miles to 1 inch) Transfrontier Maps. This affects mostly the peaks north of Kanchinjinga. These, we gather, were measured independently by the late Captain Harman in the first instance, and the heights assigned them do not rest, therefore, on the same authority as those of the peaks visible from the plains, which were included in the great general Trigonometrical Survey of India.

Take, for example, the three summits immediately north of Kanchinjinga. In the Transfrontier sheet the heights given are 23,320, 23,360, and 24,210; in Captain O'Connor's map, 23,350, 23,470, and 24,090. It would be interesting to orographers to know on what principle and by whom these alterations were made. They first appeared, we believe, in the 8-mile-to-the-inch Transfrontier sheet No. 7. It is curious that in that sheet the height of Siniolchum is omitted. In the height 19,650 given the Chorten Nima pass on Captain O'Connor's map, the text seems to show that an 8 should be substituted for the 9. The height of the Yeumtso La is reduced from 17,040 to 15,800 feet, and that of the Guicha La from 16,430 to 15,300 feet. These alterations need confirmation. The height of the termination of the Zemu Glacier, or rather, of the confluence close to it, is given as 12,800 feet: 13,000 feet may safely be quoted by geographers as the lowest limit of glaciers in this region.

The present volume supersedes an earlier edition, which had become obsolete. The primary object of its compilers has been, apparently, to afford such information as might be useful in the case of military operations on the Tibetan frontier, or a march on Lhasa. A number of routes are described in more or less detail as far as concerns the difficulties of the ground, the character of the paths, the nature of camping-grounds, and the means of crossing torrents. Neither scenery nor scientific observation find much place in the notes here provided. But the practical information affurded will naturally be of great use to

* 'Routes in Sikkim,' compiled in the Intelligence Branch of the Quarter-master General's Department in India, by Captain W. F. O'Connor, Royal Garrison Artillery. Calcutta, November, 1890. 
travellers. The routes described range from the well-known horsepaths round Darjeeling to the remote passes east and north of Kanchinjinga. Perhaps the most novel piece of exploration recorded is Captain O'Connor's passage of the Chorten Nima pass in 1896, and his journey, within the Tibetan frontier, from it eastwards to the Kongra La and Giaogong. Captain O'Connor was the first European to visit the head of the Lhonak valley, which he describes in the following terms :-

"The whole of the district drained by the Naku Chu and Langpo Chu is called Lhonak, meaning ' the black south,' and is regarded by the Tibetans as their own property, and they very much resent the appearance there of any foreigner. . . The actual head of the valley is a chaotic mass of glacier and moraine. There is said to be a pass, the Jonsong La, leading out of this valley into Nepal, but I was unable to ascertain whereabouts it lay; from the general configuration of the country it must be extremely lofty and difficult."

It is curious that Captain O'Connor should make no reference either to the accounts given by the native explorers, Rinsing and Chandra Das, of the Jonsong La, or to its passage in 1899 by an English party, of which Mr. C. Dover, of the Public Works Department in Sikhim, a contributor to the present road-book, was a member. It is true that it is not likely, judging from Mr. D. Freshfield's description (Alpine Journal, August, 1890) that this route will prove of much use for military purposes. We may note that Mr. Freshfield has stated that the gap to which he was led by Rinsing, the native explorer, as the Chorten Nima La, was not that pass, but a gap further east, connecting two sources of the Teesta (Alpine Journal, May, 1901).

The accounts of the Kang La and Guicha La routes are meagre; and the former pass is a long way from either Kabur or Kabru. On what may be called by comparison the main roads of Sikhim and the approaches to the Chumbi valley, the information given appears to be both accurate and sufficient. A route to Lhasa, an extract from an old native surveyor's report, may excite the envy and emulation of European travellers.

Lists of the bungalows kept up-perhaps this is hardly the right word, considering the condition of many of those in Independent Sikhim-and of circular tours, which may be conveniently made from Darjeeling, are added as an inducement to travellers. Distances are given in miles; in one case between Yoksun and Jongri, three marches are allowed for 17 uphill miles, a significant relation between time and space. Mr. Dover, however, and a worn-out troop of coolies descended them in one day in 1899.*

* With regard to the discrepancy in heights referred to above, and the omission of that of $\mathrm{D}_{2}$, Mr. Douglas Freshfield sends us the following note, which he has recently received from Colonel St. G. Gore, R.E., the Surveyor-General of India :- 